\title{
Group identity, ideology or recognition? Lawmakers' support for gender quotas in Latin America
} ¿ldentidad de grupo, ideología o reconocimiento? El apoyo de los y las legisladoras a las cuotas de género en América Latina

\section{Asbel Bohigues}

Postdoctoral researcher, Universidade Federal de Minas Gerais (Brasil). asbogar@rpd.ufmg.br. ORCID: https://orcid.org/0000-0002-9875-7743

\section{Jennifer M. Piscopo}

Associate Professor of Political Science, Occidental College (Estados Unidos). piscopo@oxy.edu. ORCID: https://orcid.org/0000-0002-9043-1810

How to cite this article: Bohigues, Asbel y Piscopo, Jennifer M. "Group identity, ideology or recognition? Lawmakers' support for gender quotas in Latin America". Revista CIDOB d'Afers Internacionals, issue 127 (April de 2021), pp. 95-120. DOI: doi.org/10.24241/rcai.2021.127.1.95/en

\begin{abstract}
The adoption and improvement of gender quota laws depend on political elites, but which lawmakers believe quotas are necessary? To answer this question, we use data from surveys of the elites in 13 Latin American parliaments. The findings are unexpected, both at national and party levels: the strength of already-existing quotas does not perfectly correlate with support for quotas, and the attitudes of political parties on the matter are not consistent. At the individual level, three pro-quota groups are identified: women, the left, and those who recognise the problem of gender inequality. When comparing the significance of these three groups, it is observed that women lawmakers will always be more supportive than men, regardless of ideology and the degree of recognition of the problem.
\end{abstract}

Key words: gender quotas, elites, gender inequality, Latin America, women MPs
Resumen: La adopción y mejora de las leyes de cuotas de género depende de las élites políticas, pero ¿qué legisladores y legisladoras creen que las cuotas son necesarias? Para responder a esta pregunta, se utilizan datos de encuestas a élites de 13 parlamentos latinoamericanos. Los resultados son inesperados, tanto a nivel nacional como de partido: la fuerza de las cuotas ya existentes no correlaciona exactamente con el apoyo a las cuotas, y los partidos políticos no mantienen actitudes coherentes al respecto. En el nivel individual, se identifican tres grupos favorables a las cuotas: las mujeres, la izquierda y quienes reconocen el problema de la desigualdad de género. Al comparar la importancia de estos tres grupos, se observa que las legisladoras siempre estarán más a favor que los legisladores, independientemente de la ideología y del grado de reconocimiento del problema.

Palabras clave: cuotas de género, élites, desigualdad de género, América Latina, mujeres parlamentarias 
Gender quotas are the most popular electoral reforms of the last 30 years. Over 75 countries worldwide have adopted gender quota laws, which either require political parties to run certain percentages of women candidates or reserve certain numbers of legislative seats for women (Hughes et al., 2019). Gender quotas are found from Spain to Indonesia, in democracies, semi-democracies, and non-democracies, and in countries rich and poor. Latin America launched the contemporary quota wave in 1991, when Argentina adopted a quota law requiring that political parties nominate 30 percent women, and has remained at the vanguard ever since (Htun and Jones, 2002; Piscopo, 2015; SchwindtBayer, 2018). Since 2015, all Latin American countries save Guatemala and Venezuela have implemented candidate quotas for women. ${ }^{1}$

The widespread adoption of gender quotas suggests that Latin American policymakers and citizens have

In identifying which legislators support quotas and which do not, we give some insights into which elites may drive the future successes or even rollbacks of quotas in Latin America.

reached consensus on using state power to guarantee women's right not just to elect, but to be elected (Piscopo, 2015). At the same time, the region's quota laws differ in their design and thus effectiveness, suggesting variation among lawmakers' preferences. For instance, legislators in Brazil and Panama have preserved loopholes allowing parties to shirk the requirement (Freidenberg, 2019; Wylie, 2018), while in Argentina, only four deputies voted against raising the $30 \%$ quota to gender parity (Infobae, 2017). At the individual level, women legislators in Latin America report continued resistance to their political inclusion, despite how quota adoption otherwise suggests support for democratizing political power (Piscopo, 2015; Schwindt-Bayer, 2018). Understanding which political elites support gender quotas, then, matters for whether countries may adopt stronger laws in the future or, as more conservative forces gain power in the region, protect these laws from repeal. Elites' efforts - or lack thereof - to promote women in politics also send cues to citizens about whether or not women have the capacity to govern (Morgan and Buice, 2013). Although many other factors shape when and why quotas are adopted and strengthened, or weakened or repealed, individual parliamentarians' attitudes about quotas matter for these outcomes.

1. Venezuela's Consejo Nacional Electoral applies a 50\% percent quota when evaluating parties' lists, but this norm is not mandated by law and enforcement is not transparent. 
Consequently, in identifying which legislators support quotas and which do not, we give some insights into which elites may drive the future successes or even rollbacks of quotas in the region. We explore variation in elite attitudes towards gender quotas using data from the 2015-2018 survey wave of the Latin American Elites Database from the University of Salamanca (PELA-USAL). In this survey wave, legislators were asked to agree or disagree with the statement, "quotas are necessary to increase the number of women in parliament." To understand which legislators manifested support for quotas, we use questions that measure legislators' personal and political characteristics, such as gender and ideology, respectively, as well as questions that measure legislators' recognition about the problem of gender inequality. Specifically, we leverage two questions in particular: whether lawmakers express concern, meaning they view gender inequality as an important problem for the country, and whether legislators see bias, meaning whether they acknowledge that women face discrimination when pursuing political careers. These latter questions are unique, because they go beyond revealing whether legislators prefer equality, and tell us how legislators perceive and interpret inequality.

Our results address two outstanding questions about support for gender quotas in Latin America. First, we find that previous quota adoption does not signal current elite agreement at the country level or within parties. In an aggregate analysis of legislators' support for gender quotas by country and then by party, we find no evidence that countries with strong quotas or longstanding quotas have legislators that are more supportive overall. We also find no consistent consensus on quotas by party, whether among parties in countries with strong quotas or among left parties. These results point to important individual-level variation in support, which cannot be wholly explained by countries' previous policy adoption and parties' ideology.

Second, turning to the individual-level determinants, we build on studies of citizens' support for quotas (Barnes and Córdova, 2016) and address whether equality-minded voters should prefer women (Keenan and McElroy, 2017) or leftists (Htun and Power, 2006; Beauregard, 2018). In our multilevel model, we find that three individual factors predict support: group identity (being a woman), ideology (being a leftist), and recognizing the problem (expressing concern and seeing bias). Other determinants at the individual level, such as legislators' career trajectories and family backgrounds, and at the country level, such as the proportion of women already seated in parliament, have no effect. Turning to marginal effects, we find that gender matters above-and-beyond ideology and recognition: women leftists support quotas more than men leftists, and women "recognizers" support quotas 
more than men "recognizers." Even a woman blind to gender bias in political careers supports quotas more than a man with the same blindness. Our findings underscore the enduring strength of the link between group identity and favoring policies that benefit one's social group.

\section{Explaining mass and elite support for women legislators}

Gender quotas are recognized as the "fast track" for electing more women (Dahlerup and Freidenvall, 2005). Their implementation rapidly raises women's descriptive representation - that is, the numbers of women in office. Support for gender quotas, then, should be shaped by preferences for women's descriptive representation generally as well as beliefs about why women remain underrepresented relative to men. These attitudes may not cohere however, because gender quotas constitute a form of positive action, meaning the state acts affirmatively to prevent discrimination at the outset, rather than sanctioning bad actors after the discrimination occurs (Piscopo, 2015). Individuals may want more women in office, but may disapprove of state intervention (Batista and Porto, 2020); not recognize that women face discrimination in politics (Dahlreup, 2016; Josefsson, 2020; Meier, 2012); or recognize that women face discrimination but still prefer that women make gains in politics "naturally," as social attitudes evolve over time (Dahlerup and Freidenvall, 2005).

\section{Attitudes towards women's descriptive representation}

Women and feminists are more likely to prefer more women in office, all else equal (Rosenthal 1995). This preference emerges from the conceptual link between descriptive and substantive representation, with voters believing that members of their group will better represent their groups' interests (Clayton, O'Brien, and Piscopo, 2019). The descriptive-substantive link especially drives women's preferences, meaning that women survey respondents support women candidates for policy reasons (Allen and Cutts, 2016; Espírito Santo, 2016). Additionally, those with higher education and leftist values have baseline preferences for women candidates over men candidates (Dolan and Lynch, 2015). Men and women who view men's dominance of 
elected office as undemocratic favor increases to women's descriptive representation (Espírito Santo, 2016). Feminist beliefs (Campbell and Heath, 2017) but also benevolent gender stereotypes - like believing that women are emotionally better suited for politics (Dolan and Sanbonmatsu, 2009) - also increase preferences for women's descriptive representation. Similarly, as public distrust with traditional elites rises, voters prefer more women in office (Morgan and Buice, 2013) and parties indeed nominate more women (Funk et al., 2017; Valdini, 2019).

Together, the literature emphasizes the importance of gender, left ideology, feminist principles, and benevolent sexism. These results come largely from observational or experimental survey data conducted using voter samples. Elite samples are less common, but yield similar results. In Spain, women, leftists, and those holding benevolent stereotypes such as beliefs that women govern more gently or more sensibly - supported increasing women's descriptive representation (Pastor Yuste and Iglesias-Onofrio, 2018). At the same time, many

Group identity (being a woman), ideology (being a leftist), and recognizing the problem (expressing concern and seeing bias) are the most salient individual-level determinants of Latin American elites' support for gender quotas. elites believe that preferring women's descriptive representation comes at the expense of ensuring the most deserving hold elected office (Annesley et al., 2019; Pastor Yuste and Iglesias-Onofrio, 2018). The argument that gender quotas undermine merit - despite the absence of empirical evidence (O'Brien and Piscopo, 2018) - suggests that support for gender quotas may require more than a baseline preference for having more women in office.

\section{Support for gender quotas}

Gender quotas differ in kind from other gender equality policies: rather than simply make certain behaviors illegal, subject to sanction after the violation has occurred, they require that the state take positive action, preventing discrimination before it occurs (Piscopo, 2015). This important contrast notwithstanding, support for gender quotas remains understudied. Studies on Global North cases highlight determinants similar to those shaping favorability towards increased descriptive representation for women, including group identity and feminist values (Keenan and McElroy, 2017) and left ideology (Beauregard, 2018). Looking at the case of gender quotas for 
company boards, support appeared highest in countries with high support for interventionist policies generally, and lowest in countries where women appeared more integrated into the labor market. Said another way, where women appear more equal to men already, citizens express less desire for gender quotas (Möhring and Teney, 2019).

In Latin America, support for gender quotas appears strongest among women and among those citizens (women and men) who support government action to improve citizens' wellbeing (Barnes and Córdova, 2016). This finding holds in Brazil, where benevolent sexism also matters: survey respondents who hold gender stereotypes associating women with greater compassion and more honesty are more likely to support quotas (Batista and Porto, 2020). For men, favoring government intervention and/or believing that women are morally "better"

Being a woman matters more than being a leftist or recognizing gender inequality. Even women on the right and even women unconcerned with gender inequality and failing to see bias would be more supportive of quotas than men.

may tip the balance towards supporting gender quotas, even after controlling for left ideology.

Finally, the few studies examining elite attitudes reveal the continued importance of group identity (being female) and left ideology (Htun and Power, 2006; Dubrow, 2010; Xydias, 2014). Broader awareness of how gender discrimination affects women's political careers emerges as an additional dimension.

In Uruguay, for example, women elites believe that their political underrepresentation results from bias, whereas men explain that women's absence emerges because women and men are "naturally" different on traits like ambition (Josefsson, 2020). A similar divergence appeared in Belgium, with women seeing discrimination and viewing quotas as necessary, and men doubting both. $64 \%$ of women party members agreed that "women get fewer chances in politics than men," compared to a mere $10 \%$ of men (Meier, 2012: 164). Consequently, $68 \%$ of men agreed that "quotas are redundant because women make their way without them," compared to $10 \%$ of women (Meier, 2012: 164). Even in egalitarian Denmark - which has no gender quota law - women MPs were more likely than men MPs to attribute women's political underrepresentation to bias against women (Dahlreup, 2018). Studies of elite attitudes matter, as these attitudes may not map onto country-level policy outcomes. Both Belgium and Uruguay have gender quota laws, but persistent individual-level resistance among elites, especially men. Yet elite attitudes towards quotas are usually not measured directly, but are inferred using the composition of the legislatures that adopt gender quotas. 
Literature explaining quota adoption has emphasized system-level variables, such as executive support, pressure from women's and feminist movements, and windows of opportunities created by democratization (Htun and Jones, 2002; Krook, 2009; Towns, 2012). These factors explain why legislatures vote "yes" but not whether individual legislators or those who follow in office genuinely support quotas. In Latin America, women party elites raised opponents' costs of disagreement (Valdini, 2019). Feminists leveraged discourses about democracy and equality, arguing that sexist or machista men belonged to earlier, undemocratic or even feudal eras (Baldez, 2004; Towns, 2012; Piscopo, 2016b). Similarly, women in right parties publicly opposed quotas initially, following the party line. Then, as reforms gained momentum and as party leaders' sexism became more transparent, right-wing women saw benefits to joining quota coalitions (Baldez, 2004; Piscopo, 2016b; Hinojosa et al., 2018). As gender quotas become popular, supporters find it easier to speak, while opponents find it easier to remain silent. These dynamics may further explain why government ideology does not correspond with quota adoption. Both right and left governments in Latin America adopted gender quotas and passed reforms strengthening them (Funk et al., 2017).

\section{Predicting Latin American legislators' support for quotas}

Gender quota laws' near universal adoption in Latin America suggests that political elites outwardly accept affirmative action (Piscopo, 2015). Indeed, public criticisms of gender parity are usually muted (Annesley et al., 2019: 204; Piscopo, 2016a). Yet political elites may offer the politically correct answer in public, while holding other views in private. Drawing from the literature reviewed above, three individual-level factors appear consistently related to support for women's descriptive representation and for gender quotas: gender, ideology, and recognition of inequality and bias.

First, group identity matters. Women more than men favor increasing women's descriptive representation and favor adopting gender quotas. Since group representatives are imagined to deliver policies that benefit the group, women may prefer gender quotas because of the link between descriptive and substantive representation, or because women perceive quotas as fair correctives to gender discrimination as well as useful for advancing their own political careers. 
H 1. Women Legislators support gender quotas more than men Legislators.

Second, ideology matters. Legislators on the left support quotas more, no matter their gender (Htun and Powers, 2006). Citizen support for gender quotas also appears highest in those countries with strong norms favoring government action (Barnes and Córdova, 2016; Möhring and Teney, 2019), an ideology traditionally associated with the left.

H 2: Leftist Legislators support gender quotas more than non-left Legislators.

Third, whether and how legislators recognize gender inequality matters. As a baseline, legislators need to express concern about the importance of the problem. A stronger test is not just expressing concern, but actually seeing that bias (rather than "natural" differences between women and men) contributes to inequality. Folks can attribute women's political underrepresentation to systematic discrimination, or to differences in women's political interests or ambition (Josefsson, 2020). Those who see bias should especially favor gender quotas, because recognizing bias locates fault with the system, and quotas are a system-level response.

H 3: Support for gender quotas will be higher among those who see gender inequality as an important problem in the country.

H 4: Support for gender quotas will be higher among those who see bias in women's pursuit of political careers.

Finally, group identity might matter above and beyond ideology and recognition. Many right-wing women in Latin America eventually joined pro-quota coalitions (Baldez, 2004; Piscopo, 2016b; Hinojosa et al., 2018). Additionally, women are more likely to see bias in women's political careers when compared to men (Dahlerup, 2018; Josefsson, 2020; Meier, 2012).

H 5: Women will support quotas more than men, even when similarly situated in terms of ideology and recognition.

\section{Methodological approach}

To explore the factors shaping legislators' individual-level support for quotas, we rely on survey data gathered by the Latin American Elites Database from the University of Salamanca (PELA-USAL). The questionnaires are administered in the first months of the term, via face-to-face interviews with legislators in the lower or unicameral chambers. Legislators are randomly chosen from political parties, and responses are weighted according to parties' size in the parliament. Since 2015, PELA-USAL has included a battery of questions regarding gender inequality. Among them, legislators are asked the following question, where 1 equals strongly 
disagree and 5 equals strongly agree: "Quotas are necessary to increase the number of women in parliament."

Importantly, the PELA-USAL surveys are anonymous. Robertson et al. (2018) show that subjects feel more comfortable when surveys are conducted anonymously. Non-anonymous surveys suffer from social desirability bias, and might underestimate or overestimate certain responses. Thus, legislators interviewed for the PELA-USAL surveys express their opinions without pressure or constraints from constituents, party leaders, and party members (Saiegh, 2009). Given the public pressure to support gender quotas (Baldez, 2004; Towns, 2012), the anonymity of the PELA-USAL surveys limits legislators' tendency to give the politically correct response. To further protect respondents' anonymity, legislators whose parties obtained five or fewer seats are not identified by party, but grouped into the "others" category.

Table 1. PELA-USAL surveys included in the study (2015-2020)

\begin{tabular}{l|c|c|c|c} 
Country & Legislature & Fieldwork year & Surveyed & $\%$ Chamber \\
\hline Bolivia & $2015-2020$ & 2015 & 93 & 71.5 \\
\hline Colombia & $2018-2022$ & 2018 & 69 & 40.1 \\
\hline Costa Rica & $2018-2022$ & 2018 & 44 & 57.1 \\
\hline Dominican Rep. & $2016-2021$ & 2017 & 51 & 32.1 \\
\hline Ecuador & $2017-2021$ & 2017 & 88 & 64.2 \\
\hline El Salvador & $2018-2021$ & 2018 & 79 & 94.0 \\
\hline Guatemala & $2016-2020$ & 2016 & 78 & 48.7 \\
\hline Honduras & $2018-2022$ & 2018 & 92 & 71.9 \\
\hline Mexico & $2015-2018$ & 2016 & 100 & 20.0 \\
\hline Nicaragua & $2017-2022$ & 2017 & 59 & 64.1 \\
\hline Peru & $2016-2021$ & 2018 & 73 & 56.2 \\
\hline Uruguay & $2015-2020$ & 2015 & 69 & 60.7 \\
\hline Venezuela & $2016-2021$ & 2016 & 67 & 40.1 \\
\hline
\end{tabular}

Source: Own elaboration based on the Latin American Elites Database (PELA-USAL).

Our sample covers the 13 Latin American countries where the quota question is available, shown in Table 1. Six countries elected their legislature using gender parity at the time of fieldwork (Bolivia, Costa Rica, Ecuador, Honduras, Mexico, and Nicaragua). Five applied gender quotas between 30\% and 40\% (Colombia, El Salvador, the Dominican Republic, Peru, and Uruguay), and two had no quota law (Guatemala and Venezuela). The sample reflects the variety of quota 
types currently found in Latin America, from parity (which predominates in the region and in the sample) to countries with thresholds below parity and countries without quota laws. Likewise, the sample offers good variation on timing, including countries that first adopted quotas in the 1990s, such as Bolivia, Costa Rica, and Ecuador, as well as countries that did not adopt their gender quotas until the late 2000s or early 2010s, such as El Salvador, Nicaragua, and Uruguay.

We draw our measurements of all independent variables from the PELA data, including our main indicators: gender, ideology and recognition of gender inequality. We measure gender as the legislators' sex $(1=$ female and $0=$ male). For ideology, we use legislators' self-placement on the traditional left-right axis (1=left and $10=$ right).

Several questions in the PELA-USAL dataset allow us to assess legislators' recognition of gender inequality. The new battery of questions about gender attitudes asks whether "the state must implement public policies to reduce inequalities between men and women." However, this question shows little variation, with $80 \%$ or more legislators agreeing in all 13 countries. We therefore exclude it: the question could refer to many different policies, from preventing sexual violence to adopting equal pay, none of which say much about legislators' recognition of gender inequality itself. Instead, we leverage two different questions: whether legislators think that inequalities between men and women are an important problem in the country $(1=$ not important and $10=$ very important $)$ and whether legislators agree or disagree that women have the same chances as anyone to access positions of power within political parties $(1=$ agree and $5=$ disagree $){ }^{2}$ If legislators mark gender inequality as an important problem, they are concerned, and if they disagree that women have the same chances, they are seeing bias. The latter question in particular taps into conflicting understandings about why women remain underrepresented in politics (Dahlerup, 2018; Josefsson, 2020; Meier, 2012). Both questions correlate at 0.15 , indicating that they are tapping into difference attitudes.

These five variables constitute our main set of independent variables to check our hypotheses regarding support for quotas among Latin American parliamentarians. Additionally, we add a number of individual-level control variables. Firstly, we use whether legislators believe men are better political leaders than women (better leaders). If a legislator disagrees, we do not know whether they are benevolent sexists (believing women are morally superior) or egalitarian (believing women are as good as men), but we at least capture the absence of hostile

2. Note, these values are reverse coded from the original PELA-USAL survey. 
sexism (believing that men are better). Second, we use an additional measure of ideology, preference for an economy regulated either by the state or by the market (scale where $1=$ state and $10=$ market). Finally, we include an extensive battery of control variables. These are civil status ( $1=$ married, $0=$ all others); age (interval measurement); legislators' education, as well as father's and mother's education (scale where $1=$ no studies and $6=$ postgraduate studies); religiosity (scale where $0=$ atheist and $5=$ believer attending religious services more than once a week); legislator serving their first term in office $(1=y e s, 0=$ no); legislator's presence in governing party (opposition $=1$; government $=0$ ); and support for democracy (4pt scale in response to the statement, "elections are always the best mechanism to express political preferences", scale where $1=$ strongly disagrees and $4=$ strongly agrees).

At the country level, we include two variables. ${ }^{3}$ First, we control for the percentage of female legislators in the lower or unicameral chamber at the time of the fieldwork, as the presence of many or fewer women may influence legislators' perceptions of quotas' necessity. Second, we include a scale measuring the quota laws' strength. Our 13 countries reflect key variations in this area. We consider strong quota laws to have high thresholds (those at $40 \%$ or higher, meaning they are at parity or approaching parity); placement mandates for women's names on proportional lists (the standard is vertical parity, that is, men's and women's names alternating down the list); and enforcement by the electoral authorities (typically parties cannot enter the election unless they fill the quota correctly). Following Funk et al. (2017), countries receive one point for each of the following factors: having a quota, setting the threshold at $40 \%$ or higher, including a placement mandate, and including enforcement mechanisms. The result is scale ranging from 0 (no quota) to 4 (strongest possible quota). ${ }^{4}$ In our sample, Bolivia, Costa Rica, Ecuador, Honduras, and Mexico all score four: their quotas are set at parity, they require alternation of men's and women's names down the electoral list, and their electoral tribunals deny registries to non-compliant parties. ${ }^{5}$

3. Results from alternative models with different aggregate-level variables (i.e., democracy) did not significantly differ.

4. We update Funk et al.'s scores to match the strength of the country's quota law when the PELAUSAL fieldwork occurred (see table 1).

5. Honduras's quota law only applies to party primaries, and Honduras does not have a pure closed-list proportional representation system. However, in 2017, the electoral authorities issued regulations that applied "parity with alternation" to party primaries and to parties in the general election if they (i) did not hold primaries or (ii) were running in an alliance. These rules are sufficiently strenuous to code Honduras as 4 . As a robustness check, we repeated the models with Honduras coded as 3 and neither the country-level nor individual-level results changed significantly. 
The dependent variable, support for quotas, is measured as an agreement scale of five points. We recoded for three values: disagreement (1-2), neutrality (3) and agreement (4-5). As a consequence, we run a mixed-effects multilevel ologit regression, with legislators nested in countries. Before turning to these results, we examine whether legislators' support at the country or party level corresponds with countries' quota laws or parties' leftist values.

\section{Support for quotas across countries and parties}

Gender quotas have varied support across Latin American countries, with some places evincing strong support and others expressing low support. Figure 1 displays the percentage of legislators in favor, against, and neutral. Legislators in Costa Rica and Nicaragua, followed by the Dominican Republic, Ecuador, and Honduras, display near consensus in supporting gender quotas. Consensus appears unrelated to quota age: Costa Rica, Ecuador, and the Dominican Republic first implemented quotas in the 1990s, but Nicaragua lagged, not adopting its first quota law until 2012.

Overall, over $50 \%$ of legislators support quotas in every country save Uruguay and Guatemala. These two countries also lag in their adoption, with Guatemala still refusing and Uruguay not adopting its first - and very weak - quota until 2009. At the same time, low support in Guatemala and Uruguay somewhat contradicts earlier findings using citizen samples, which found higher support for quotas in countries with good governance (Barnes and Córdova 2016). Guatemala fits (low government capacity and low support), but Uruguay does not (high government capacity and low support). Uruguayan legislators either reject quotas or remain neutral and Guatemalan legislators overwhelmingly reject quotas, with nearly $60 \%$ of legislators against. While Guatemala and Uruguay have the lowest support and no quota, Costa Rica and Nicaragua have the highest support and strong quotas, suggesting that quota support may correlate with quota law strength.

Figure 2 explores this possible relationship further, presenting legislators' support of gender quotas by the country's quota strength score, described above. When viewed this way, no clear association appears between legislators' support and the current quota law's strength. The two extremes do behave as expected: we find the lowest and highest support for quotas in countries with no quota laws and strong quota laws, respectively. The no- 
quota group encompasses Venezuela and Guatemala, two of the least supportive countries identified in Figure 1. The strong quota group includes Nicaragua and Costa Rica, alongside Mexico, Bolivia, Ecuador, and Honduras. However, the middle categories do not behave as expected: support is 24 percentage points lower in countries with moderately strong quotas (quota score $=3$ ) than in countries with weak quotas (quota score $=2$ ). This latter group includes Colombia, the Dominican Republic, El Salvador and Peru. And in the moderately strong quota group, which reflects Uruguay's second and updated quota law, almost one third of legislators remain neutral about the necessity of quotas. Together, figures one and two suggest that, aside from the no quota cases and certain strong quota cases, the presence of a quota law cannot explain the full variation in current legislators' attitudes.

Figure 1. Support for quotas in 13 Latin American countries (2015-2018)

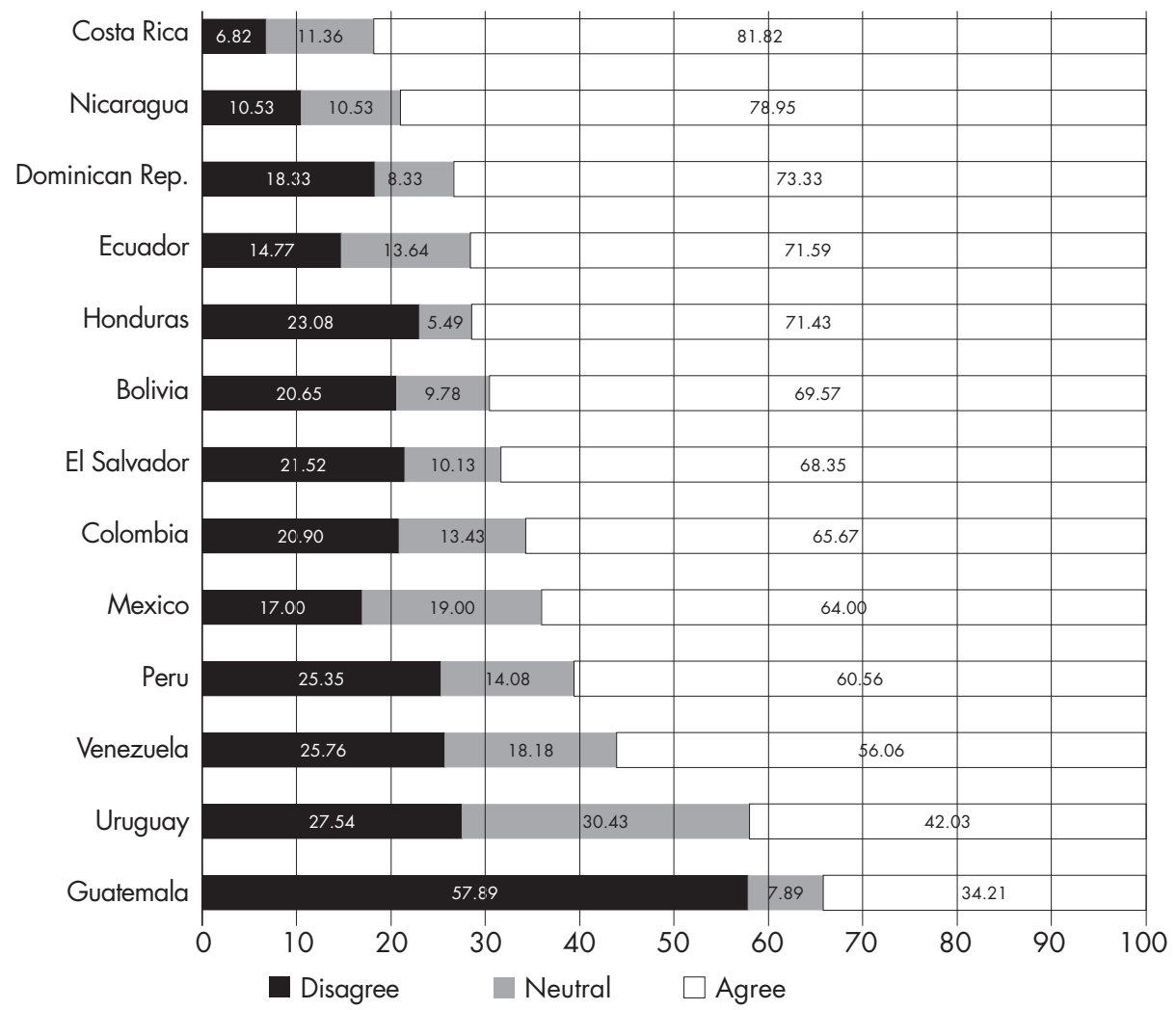

Source: Own elaboration based on the Latin American Elites Database (PELA-USAL). 
Figure 2. Support for quotas by quota strength in 13 Latin American countries (2015-2018)

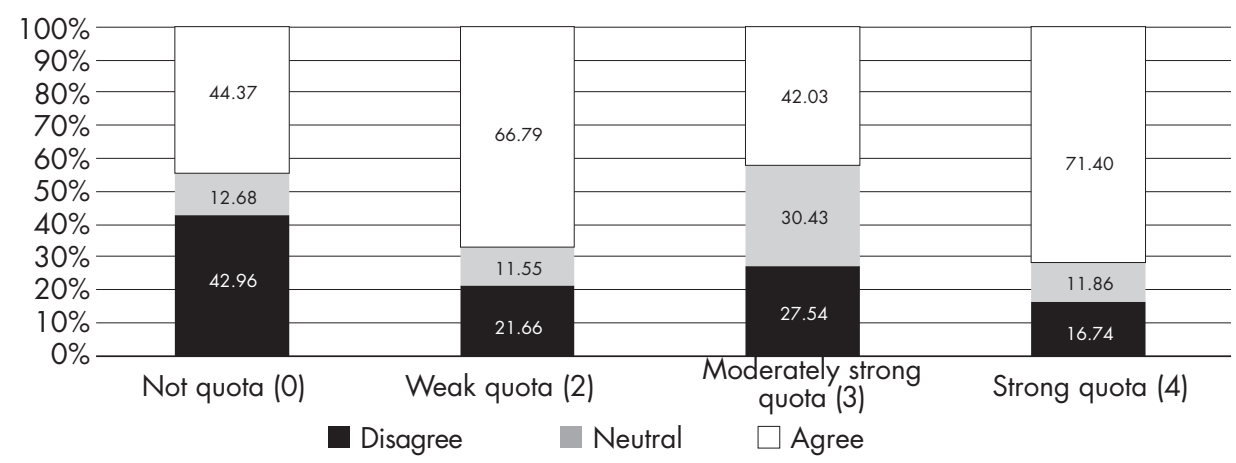

Source: Own elaboration based on the Latin American Elites Database (PELA-USAL).

Continuing with an aggregate-level analysis, we explore whether variation is explained by party ideology. Table 2 displays the main political parties of each country, and the percentage of agreement, neutrality and disagreement regarding quotas. ${ }^{6}$ Parties are ordered according to legislators' left-right position in the PELA-USAL surveys, from left (top) to right (down). Gray highlights indicate parties where two-thirds of the members take a clear position on gender quotas, whether for or against.

At first glance, most Latin American parties do not hold coherent views on gender quotas. Where consensus exists, party members are overwhelmingly favorable. Similar to the country-level results, the three countries with the most support - Costa Rica, Nicaragua, and the Dominican Republic - have parties across the ideological spectrum that clearly favor gender quotas. And Guatemala, which has the lowest support, also has the one Latin America party - Libertad Democrática Renovada (LIDER) - in which members are united in disliking quotas. Again, however, the positive relationship between quota laws' strength and high support appears in some but not all cases. Guatemala has no quota and Guatemalan parties dislike quotas; Costa Rica and Nicaragua have strong quotas, and parties like quotas. Yet Mexico and Uruguay have strong and moderately strong quotas, respectively, but present no elite consensus. Therefore, division over quotas exists within political parties across the region.

6. We include parties that hold more than five seats and have more than five interviewees 
Table 2. Support for quotas \% by political party in 13 Latin American countries (2015-2018)

\begin{tabular}{|c|c|c|c|c|c|}
\hline Country & Agree (4-5) & Political party & Disagree (1-2) & Neutral (3) & Agree (4-5) \\
\hline \multirow{4}{*}{ Costa Rica } & \multirow{4}{*}{81.82} & PAC & 0.00 & 0.00 & 100.00 \\
\hline & & PLN & 7.14 & 7.14 & 85.71 \\
\hline & & RN & 11.11 & 11.11 & 77.78 \\
\hline & & PUSC & 14.29 & 14.29 & 71.43 \\
\hline \multirow{2}{*}{ Nicaragua } & \multirow{2}{*}{78.95} & FSLN & 12.20 & 9.76 & 78.05 \\
\hline & & Partido Liberal & 0.00 & 16.67 & 83.33 \\
\hline \multirow{2}{*}{ Dominican Rep. } & \multirow{2}{*}{73.33} & PRM & 17.39 & 8.70 & 73.91 \\
\hline & & PLD & 20.00 & 12.00 & 68.00 \\
\hline \multirow{3}{*}{ Ecuador } & \multirow{3}{*}{71.59} & Alianza-PAIS & 6.98 & 11.63 & 81.40 \\
\hline & & SUMA-CREO & 21.74 & 13.04 & 65.22 \\
\hline & & PSC & 22.22 & 33.33 & 44.44 \\
\hline \multirow{3}{*}{ Honduras } & \multirow{3}{*}{71.43} & LIBRE & 4.00 & 4.00 & 92.00 \\
\hline & & $\mathrm{PL}$ & 42.86 & 4.76 & 52.38 \\
\hline & & PN & 25.71 & 5.71 & 68.57 \\
\hline \multirow{3}{*}{ Bolivia } & \multirow{3}{*}{69.57} & MAS & 17.86 & 3.57 & 78.57 \\
\hline & & UD & 21.43 & 17.86 & 60.71 \\
\hline & & PDC & 37.50 & 25.00 & 37.50 \\
\hline \multirow{4}{*}{ El Salvador } & \multirow{4}{*}{68.35} & FMLN & 9.52 & 4.76 & 85.71 \\
\hline & & GANA & 11.11 & 22.22 & 66.67 \\
\hline & & PCN & 0.00 & 22.22 & 77.78 \\
\hline & & ARENA & 34.29 & 8.57 & 57.14 \\
\hline \multirow{5}{*}{ Colombia } & \multirow{5}{*}{65.67} & $\mathrm{PL}$ & 33.33 & 25.00 & 41.67 \\
\hline & & Verde & 0.00 & 16.67 & 83.33 \\
\hline & & CR & 0.00 & 9.09 & 90.91 \\
\hline & & P de la U & 20.00 & 0.00 & 80.00 \\
\hline & & CD & 26.67 & 13.33 & 60.00 \\
\hline \multirow{3}{*}{ Mexico } & \multirow{3}{*}{64} & PRD & 25.00 & 16.67 & 58.33 \\
\hline & & PRI & 14.00 & 26.00 & 60.00 \\
\hline & & PAN & 26.09 & 13.04 & 60.87 \\
\hline \multirow{5}{*}{ Perú } & \multirow{5}{*}{60.56} & FA & 0.00 & 16.67 & 83.33 \\
\hline & & Nuevo Perú & 0.00 & 16.67 & 83.33 \\
\hline & & APP & 16.67 & 33.33 & 50.00 \\
\hline & & PPK & 36.36 & 0.00 & 63.64 \\
\hline & & Fuerza Popular & 30.56 & 11.11 & 58.33 \\
\hline \multirow{5}{*}{ Venezuela } & \multirow{5}{*}{56.06} & PSUV & 5.88 & 0.00 & 94.12 \\
\hline & & $A D$ & 20.00 & 10.00 & 70.00 \\
\hline & & UNT & 14.29 & 42.86 & 42.86 \\
\hline & & VP & 33.33 & 11.11 & 55.56 \\
\hline & & PJ & 37.50 & 37.50 & 25.00 \\
\hline \multirow{3}{*}{ Uruguay } & & FA & 21.05 & 36.84 & 42.11 \\
\hline & 42.03 & PC & 37.50 & 25.00 & 37.50 \\
\hline & & PN & 33.33 & 23.81 & 42.86 \\
\hline & & FCN & 50.00 & 25.00 & 25.00 \\
\hline & & UNE & 52.94 & 5.88 & 41.18 \\
\hline Guatemala & 34.21 & TODOS & 40.00 & 10.00 & 50.00 \\
\hline & & LIDER & 66.67 & 0.00 & 33.33 \\
\hline
\end{tabular}

Source: Own elaboration based on the Latin American Elites Database (PELA-USAL).

Revista CIDOB d'Afers Internacionals, n.127, p. 95-120. Abril 2021

ISSN: $1133-6595$ - E-ISSN:2013-035X - www.cidob.org 
Table 2 also indicates that party ideology cannot fully explain support for gender quotas. Left parties (those scoring 4 or below on the 10-pt ideological scale) are marked in bold, though not all countries have clear left parties. Among left parties, many have no consensus, with their members neither approving nor disapproving of quotas, as shown by the Partido de la Revolución Democrática (PRD) in Mexico and Frente Amplio (FA) in Uruguay. And among parties of the right, many legislators do express consensus: more than two thirds of legislators in Restauración Nacional (RN) in Costa Rica, Partido Nacional (PN) in Honduras and Partido de Concertación Nacional (PCN) in El Salvador agree that quotas are necessary. Across many parties, significant numbers of legislators ( $>33 \%)$ express neutral attitudes towards gender quotas, including those in right parties (Primero Justicia, PJ, in Venezuela) and in left parties (FA in Uruguay, again). The Uruguay findings echo research that underscores Uruguayan elites' great reluctance to adopt and later reform the quota law (Johnson, 2018). It's not that the Uruguayan left opposes quotas, but that more than one third of legislators evince neither support nor rejection.

Taken together, the data show varying levels of quota support by country and by parties. No consistent correspondence emerges between quota support, on the one side, and quota strength at the country level and left-right ideology at the party level, on the other. This analysis points towards explanations at the individual level.

\section{Individual determinants of support for quotas}

To understand the individual-level determinants of support, we combine the PELA-USAL data with the two country-level measures (quota strength and proportion of women legislators) and perform a multilevel mixed-effects ologit regression. Figure 3 displays the mixed-effects ologit regression, with the coefficients for each variable represented with $95 \%$ confidence intervals. The results provide support for our hypotheses that agreement with quotas is strongest among women $(\mathrm{H} 1)$, leftists $(\mathrm{H} 2)$, and those who recognize gender inequality, including both legislators who express concern that gender inequality is an important problem (H3) and legislators who believe that women face bias within the political parties (H4). None of the control variables have significant effects on individual legislators' support for gender quotas. Neither political backgrounds nor family backgrounds matter, nor does legislators' opinion on whether men make better political leaders. Quota laws' strength further does not affect legislators' position on quotas, and neither does the current proportion of women actually seated in the legislature, leaving the explanation for quota support at the individual level, as our hypotheses expected. 
Figure 3. Individual determinants of support for quotas by legislators in 13 Latin American countries (2015-2018)

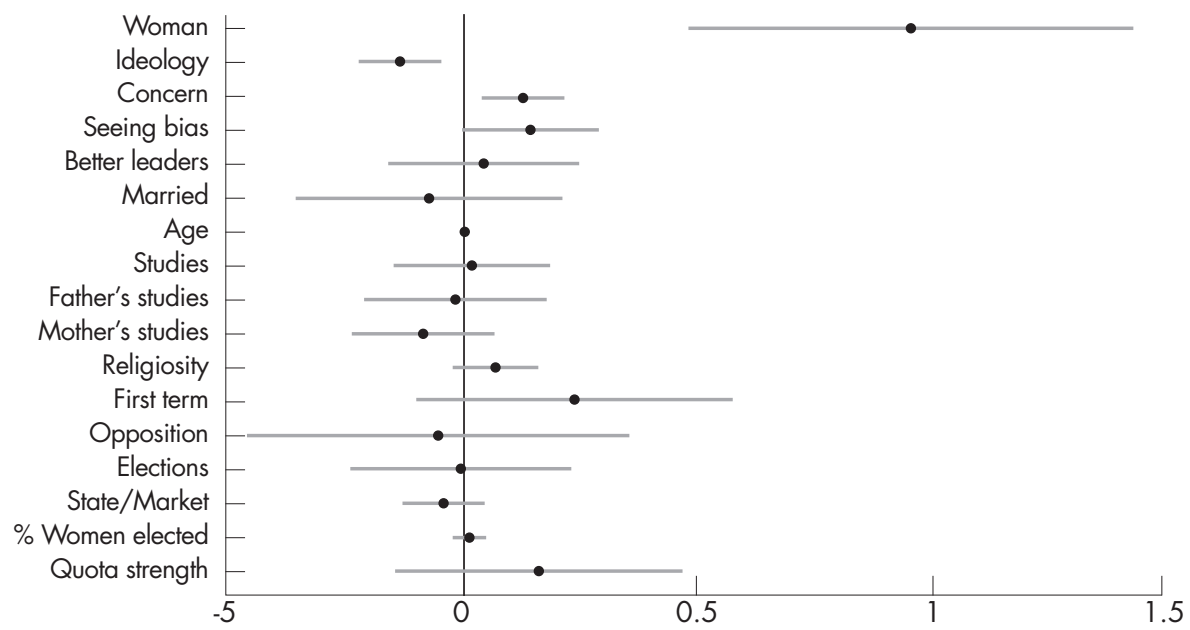

Note: Multilevel mixed-effects ologit regression. 790 observations in 13 groups. Individuals' responses are weighted for parties' size.

Source: Own elaboration

In general, the legislators that support quotas more are women $(0.95$, $\mathrm{p}<.01)$, leftists $(-0.13, \mathrm{p}<.01)$ but not statists (those who preferred a statecontrolled economy). Quota supporters are also "recognizers," meaning those who see gender inequality as an important national problem $(0.13$, $\mathrm{p}<.01)$ and those who see that women lack the same chances as men within the political parties $(0.14, \mathrm{p}<.1)$.

In $\mathrm{H} 5$, we theorized an interaction between these latter factors, in that women on the left would support quotas more than their male co-partisans, and that women may express concern about gender inequality and see bias more than men. The marginal effects of ideology and recognition by gender test $\mathrm{H} 5$ and therefore address an important question: which legislator should quota proponents seek to elect? While some scholars point to the important role women legislators played in previous rounds of quota adoption (Krook, 2009; Piscopo, 2016b; Towns, 2012), others have argued that electing leftists may matter for garnering quota support (Htun and Power, 2006; Beauregard, 2018). 
Figure 4 displays the predicted support for gender quotas over increasing values of ideology (left to right), concern about gender inequality (no importance to high importance), and seeing bias within the political parties (agreeing to disagreeing that women have the same chances). Each panel reveals the overwhelming importance of legislators' group identity, with women systematically more supportive than men in every case. At each value of ideology, concern, and seeing bias, women are more supportive than men. The gap is less pronounced among left legislators, but still noticeable.

Moreover, the marginal effects show a higher degree of coherence among women compared to men, as shown by the sharper slope when predicting men's quota support when compared to women's quota support in all three conditions. For example, there is a 19-point difference between the extreme right and extreme left for women, while this difference for men is 27 points. A similar divergence between men and women appears over levels of concern for gender inequality: a 19-point difference for women and a 26-point difference for men. Finally, going from seeing no bias to seeing a lot of bias raises quota support for women by 9 points, and for men by 12 points.

These comparisons focus on the gender gap between women and men given the same value of ideology, concern, or seeing bias. Another comparison looks across values, to see whether a man with a certain ideology or belief is predicted to support gender quotas more than a woman with a differing ideology or belief. We find this circumstance in two cases: a) a far left man (ideology=1) is $73 \%$ likely to support gender quotas, compared to a far right woman, who is $68 \%$ likely to support quotas (ideology=10) or $70 \%$ likely (ideology=9); b) the man most concerned about gender inequality (importance $=10$ ) is predicted to support gender quotas more than the least concerned woman (importance $=1$ or 2): he is $71 \%$ likely to support gender quotas, compared to her, who is just 67 or $70 \%$ likely to express support, respectively.

In any other comparison between women and men at different values, women remain more supportive than men. Even a rightist woman at position 9 in the 1-10 ideology axis is predicted to support gender quotas more than a leftist man at position 2 . The differences in predicted probabilities are small, but present. More significantly, when seeing bias, women are systematically more supportive than men; no combination shows men as more supportive. Even a woman that denies the fact that women actually face more difficulties in their political careers is predicted to support quotas more than a man who fully recognizes the fact that women face difficulties (78\% compared to 71\%). The link between group identity and supporting policies that benefit one's group - in this case, women supporting gender quotas - remains strong. 
Figure 4. Marginal effects by gender on support for quotas in 13 Latin American countries (2015-2018)
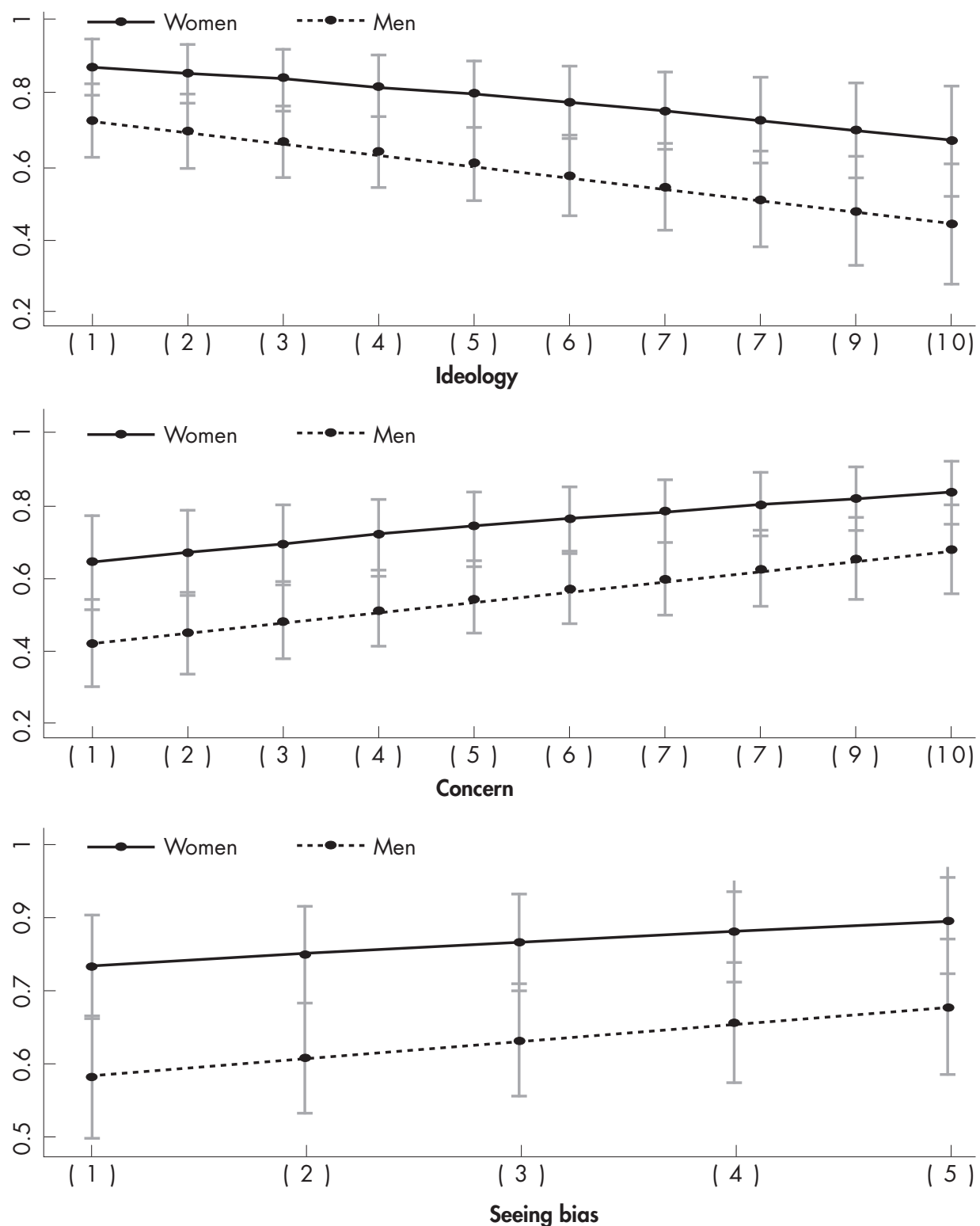

Predicted outcome: agreement on the necessity of quotas. Source: Own elaboration.

Revista CIDOB d'Afers Internacionals, n.127, p. 95-120. Abril 2021

ISSN: $1133-6595$ - E-ISSN:2013-035X - www.cidob.org 


\section{Conclusions}

Gender quotas remain the most popular and significant electoral reform of the past 30 years (Hughes et al., 2018; Krook 2009; Piscopo 2015). Previous research largely focused on citizens' public opinion, showing which citizens in which contexts would support quota adoption. Our study shifts the focus from citizens to legislators. Yet our results indicate that widespread adoption may not indicate widespread consensus among current political elites, at least not when legislators can express their true views on the matter, as in the PELA-USAL surveys.

We find that group identity, ideology, and recognition of gender inequality are the most salient individual-level determinants of Latin American elites' support for gender quotas. The overwhelming importance of group These three factors predict whethidentity in shaping legislators' support for er legislators view quotas as necesquotas underscores the link between group sary, more than other aspects of identity and policy representation.

the legislators' personal and professional background, more than the strength of the existing quota law, and more than the number of women present in the parliament. For quota strength, some countries behave as expected (strong quotas, strong support and no quotas, weak support), whereas others do not. For women in parliament, the absence of an effect for this variable underscores our main finding: it's not the proportion of women legislators that makes parliaments more supportive of gender quotas, but that individual woman legislators are more supportive, full stop.

Moreover, being a woman matters more than being a leftist or recognizing gender inequality. Those looking for more and stronger gender quota laws can vote for women candidates, left candidates, or candidates who recognize the problem of gender inequality, but our results show that, if they had to choose one, they should prioritize women. Among elites on the left, and among those concerned with gender equality and those seeing bias, women still support gender quotas more than men.

The anonymity of the PELA-USAL surveys may help explain the key role of group identity in our findings. Our data predict that even women on the right and even women unconcerned with gender inequality and failing to see bias would be more supportive than similarly-situated men. Were there social desirability in the legislators' responses - were their responses not anonymous - we may see more men agreeing, or more right-leaning women disagreeing, given pressure to follow party lines or to give the politically correct response. 
The overwhelming importance of group identity in shaping legislators' support for quotas underscores the link between group identity and policy representation. Even if institutions and opportunity attenuate the link between descriptive and substantive representation in practice, members of social groups (like women) favor policies that benefit their social group (like gender quotas). This link does not mean, however, that men legislators are not allies in countries' advancement towards gender equality. Gender quotas are a particular kind of gender equality policy, in that they can displace men legislators and ultimately chip away at men's political power (Piscopo, 2015; Valdini, 2019). Future research on elites' opinions should examine other types of gender equality policy support, such as abortion, childcare, equal pay, and other forms of positive action. Such research would offer a more complete picture of which gender equality measures elites do or do not support.

\section{Bibliographical references}

Allen, Peter and Cutts, David. «Exploring sex differences in attitudes towards the descriptive and substantive representation of women». The British Journal of Politics and International Relations, vol. 18, n. ${ }^{\circ} 4$ (2016), p. 912-929.

Annesley, Claire; Beckwith, Karen and Franceschet Susan. Cabinets, Ministers, and Gender. New York: Oxford University Press, 2019.

Baldez, Lisa. «Elected Bodies: The Gender Quota Law for Legislative Candidates in Mexico». Legislative Studies Quarterly, vol. 29, n. 2 (2004), p. 231-258.

Barnes, Tiffany and Córdova, Abby. «Making Space for Women: Explaining Citizen Support for Legislative Gender Quotas in Latin America». The Journal of Politics, vol. 78, n. ${ }^{\circ} 3$ (2016), p. 670-686.

Batista Pereira, Frederico and Porto, Nathália. "Gender Attitudes and Public Opinion towards Electoral Gender Quotas in Brazil». Political Psychology, Online first, doi: 10.1111/pops.12655.

Beauregard, Katrine. "Partisanship and the gender gap: support for gender quotas in Australia». Australian Journal of Political Science, vol. 53, n. 3 (2018), p. 290-319.

Campbell, Rosie and Heath, Oliver. «Do Women Vote for Women Candidates? Attitudes toward Descriptive Representation and Voting Behavior in the 2010 British Election». Politics \& Gender, vol. 13, n. ${ }^{\circ} 2$ (2017), p. 209-231. 
Clayton, Amanda; O’Brien, Diana and Piscopo, Jennifer M. "All Male Panels? Representation and Democratic Legitimacy». American Journal of Political Science, vol. 63, n. ${ }^{\circ}$ (2019), p.113-129.

Dahlerup, Drude. "Gender Equality as a Closed Case: A Survey among the Members of the 2015 Danish Parliament». Scandanavian Political Studies, vol. 41, n. ${ }^{\circ} 2$ (2018), p.188-209.

Dahlerup, Drude and Freidenvall, Lenita. «Quotas as a 'fast track' to equal representation for women: Why Scandinavia is no longer the model». International Feminist Journal of Politics, vol. 7, n. ${ }^{\circ} 1$ (2005), p.26-48.

Dolan, Kathleen and Lynch, Timothy. «Making the connection? Attitudes about Women In Politics and Voting for Women Candidates». Politics, Groups, and Identities, vol.3, n.o 1 (2015), p. 111-132.

Dolan, Kathleen y Sanbonmatsu, Kira. "Gender Stereotypes and Attitudes toward Gender Balance in Government». American Politics Research, vol.37, n. ${ }^{\circ}$ 3 (2009), p. 409-428.

Dubrow, Joshua. "The importance of party ideology: Explaining parliamentarian support for political party gender quotas in Eastern Europe». Party Politics, vol.17, n. ${ }^{\circ} 5$ (2010), p.561-579.

Espírito-Santo, Ana. «Citizens' attitudes towards descriptive representation: The case of women in Portugal». European Journal of Women's Studies, vol. 23, n. ${ }^{\circ}$ 1 (2015), p.43-59.

Freidenberg, Flavia and Araúz, Harry Brown. «La representación política de las mujeres en Panamá: una propuesta para superar el dilema de coordinación entre las primarias y la paridad.» Derecho Electoral, vol. 27, n. ${ }^{\circ} 1$ (2019), p. 5-25.

Funk, Kendall D.; Hinojosa, Magda and Piscopo, Jennifer M. «Still Left Behind: Gender, Political Parties, and Latin America's Pink Tide». Social Politics, vol. 24, n. ${ }^{\circ} 4$ (2017), p. 399-424.

Hinojosa, Magda; Piscopo, Jennifer M.; Siavelis, Peter and Thomas, Gwynn. 2018. «Lessons from a Late Adopter: Chile's Electoral Reforms and Women's Representation». Paper Presented at the World Congress of the International Political Science Association, Brisbane, Australia, 22-26 July.

Htun, Mala and Jones, Mark P. «Electoral Quotas and Women's Leadership in Latin America». En: Craske, Nikki y Molyneux, Maxine (eds.) Gender and the Politics of Rights and Democracy in Latin America. New York: Palgrave, 2002, p. 32-56.

Htun, Mala and Power, Timothy. «Gender, Parties, and Support for Equal Rights in the Brazilian Congress». Latin American Politics and Society, vol. 48, n. 4 (2006), p. 83-104. 
Hughes, Melanie; Paxton, Pamela; Clayton, Amanda and Zetterberg, Pär. «Global Gender Quota Adoption, Implementation, and Reform». Comparative Politics, vol. 51, n. ${ }^{\circ} 2$ (2019), p. 219-238.

Infoabe. "Diputados aprobó la ley de paridad de género en listas electorales." Infobae.com (11 de noviembre de 2017), (en línea) [Fecha de consulta 22.06.2020].

Johnson, Niki. «Marginalization of Women and Male Privilege in Political Representation in Uruguay», En: Schwindt-Bayer, Leslie (ed.) Gender and Representation in Latin America. New York: Oxford University Press, p. 175-195.

Josefsson, Cecilia. «How candidate selection structures and genders political ambition: illustrations from Uruguay». European Journal of Politics and Gender, vol. 3, n. ${ }^{\circ} 1$ (2020), p. 61-78.

Keenan, Lisa and McElroy, Gail. "Who supports gender quotas in Ireland?». Irish Political Studies, vol.32, n. 3 (2017), p. 382-403.

Krook, Mona Lena. Quotas for Women in Politics. New York: Oxford University Press.

Meier, Petra. «Paradoxes in the Meanings of Quotas in Belgium», en: Franceschet, Susan, Krook; Mona Lena y Piscopo, Jennifer M (eds). The Impact of Gender Quotas. New York: Oxford University Press, 2012, p. 157-172.

Möhring, Katja and Teney, Céline. "Equality prescribed? Contextual determinants of citizens' support for gender boardroom quotas across Europe». Comparative European Politics, vol. 17, n. ${ }^{\circ} 6$ (2019), p. 1-30.

Morgan, Jana and Buice, Melissa. "Latin American Attitudes toward Women in Politics: The Influence of Elite Cues, Female Advancement, and Individual Characteristics». American Political Science Review, vol. 107, n.o 4 (2017), p. 644-662.

O’Brien, Diana and Piscopo, Jennifer M. «Electing Women to National Legislatures», en: Alexander, Amy; Jalalzai, Farida y Bolzendahl, Catherine (eds.) Measuring Women's Political Empowerment across the Globe. London: Palgrave Macmillan, 2018, p. 139-163.

Pastor Yuste, Raquel and Iglesias-Onofrio, Marcela. "¿Solo importa el género? Análisis de las percepciones de los parlamentarios españoles sobre la representación política descriptiva y sustantiva». Politica y Sociedad, vol. 55, n. ${ }^{\circ} 1$ (2018), p. 135-159.

Piscopo, Jennifer M. «Democracy as Gender Balance: The Shift from Quotas to Parity in Latin America». Politics, Groups, and Identities, vol. 4, n. 2 (2016a), p. 214-230.

Piscopo, Jennifer M. «When Informality Advantages Women: Quota Networks, Electoral Rules and Candidate Selection in Mexico». Government \& Opposition, vol. 51, n.o 3 (2016b), p. 487-512. 
Piscopo, Jennifer M. «States as Gender Equality Activists: The Evolution of Quota Laws in Latin America». Latin American Politics and Society, vol. 57, n. ${ }^{\circ} 3$ (2015), p.27-49.

Robertson, Ronald E; Tran, Felix W.; Lewark, Lauren N. and Epstein Robert. «Estimates of Non-Heterosexual Prevalence: The Roles of Anonymity and Privacy in Survey Methodology». Archives of Sexual Behavior, vol. 47, no. 4 (2018), p. 1069-1084.

Rosenthal, Cindy. "The Role of Gender in Descriptive Representation». Political Research Quarterly, vol. 48, n.o 3 (1995), p.599-611.

Saiegh, Sebastian. "Recovering a Basic Space from Elite Surveys: Evidence from Latin America». Legislative Studies Quarterly, vol. 34, n.o 1 (2009), p. 117-145.

Schwindt-Bayer, Leslie (ed.) Gender and Representation in Latin America. New York: Oxford University Press, 2018.

Towns, Ann. "Norms and Social Hierarchies: Understanding International Policy Diffusion "From Below"». International Organization, vol. 66, n. ${ }^{\circ}$ 2 (2012), p. 179-209.

Valdini, Melody Ellis. The Inclusion Calculation: Why Men Appropriate Women's Representation. New York: Oxford University Press, 2019.

Wylie, Kristin. Party Institutionalization and Women's Representation in Democratic Brazil. New York: Cambridge University Press, 2018.

Xydias, Christina. «Women's Rights in Germany: Generations and Gender Quotas». Politics \& Gender, vol. 10, n. ${ }^{\circ} 1$ (2014), p. 4-32. 

